\title{
Niclosamide Suppresses Proliferation, Induces Apoptosis and Inhibits Wnt/ $\beta$-catenin Signaling Pathway in Human Ovarian Cancer Cells
}

\author{
Niklozamid İnsan Over Kanseri Hücrelerinde Proliferasyonu Baskılar, Apoptozisi İndükler ve Wnt/ $\beta$-katenin \\ Sinyal Yolağını İnhibe Eder
}

\section{Ayşe Çakir Gündoğdu ${ }^{1}$, Gülnur Take Kaplanoğlu ${ }^{1}$, Hülya Sivas ${ }^{2}$, Reyhan Varol ${ }^{2}$, Cemile Merve Seymen ${ }^{1}$}

${ }^{1}$ Department of Histology and Embryology, Faculty of Medicine, Gazi University, Ankara, Turkey

${ }^{2}$ Department of Biology, Faculty of Science, Anadolu University, Eskisehir, Turkey

\section{ABSTRACT}

Objective: The aim of this study is to investigate in vitro effects of an antihelminthic drug niclosamide on human ovarian carcinoma cell line OVCAR3.

Methods: MTT assay was applied to investigate the cytotoxic effects of niclosamide on the cells. $\beta$-catenin levels in the cells were analyzed by immunocytochemistry, in order to assess the potency of niclosamide on $W n t / \beta$-catenin signaling pathway that function in cell proliferation. The effects of the drug on apoptosis were detected by TUNEL method. All the assays were also performed for chemotherapy agent 5-fluorouracil (5-FU) and anticancer effects of these two drugs were compared.

Results: It was found that niclosamide at $1 \mu \mathrm{M}$ and $2 \mu \mathrm{M}$ concentrations reduced cell viability, whereas 5-FU showed its significant proliferation inhibitory effect at higher concentrations. Niclosamide led to an increase in apoptosis while this effect was weaker compared with 5-FU. Niclosamide treatment decreased $\beta$-catenin staining in the cells significantly but 5-FU did not affect $\beta$-catenin levels.

Conclusion: The results indicate that niclosamide induces apoptosis and suppresses cell proliferation by inhibiting $W n t / \beta$-catenin signaling pathway in OVCAR-3 cells. In conclusion, these findings warrant further evaluation of niclosamide as a promising therapy for ovarian cancer.

Key Words: OVCAR-3, niclosamide, 5-fluorouracil, Wnt/ $\beta$-catenin, proliferation, apoptosis

Received: 09.21 .2018
Accepted: 12.21 .2018
ÖZET

Amaç: Bu çalışmanın amacı, antihelmintik bir ilaç olan niklozamidin insan over kanseri hücre hattı OVCAR-3 üzerindeki in vitro etkilerini araştırmaktır. Yöntemler: Niklozamidin hücreler üzerindeki sitotoksik etkilerini incelemek için MTT testi uygulanmıştır. Niklozamidin hücre proliferasyonunda görev alan Wnt/ $\beta$-katenin sinyal yolağına potansiyel etkisini değerlendirmek üzere immünositokimya yöntemi kullanılarak hücrelerdeki $\beta$-katenin seviyeleri analiz edilmiştir. İlacın apoptozise etkileri TUNEL yöntemi ile değerlendirilmiştir. Tüm deneyler ayrıca kemoterapi ajanı olan 5-florourasil (5-FU) için de yapılarak iki ilacın antikanser etkileri karşılaştırılmıştır.

Bulgular: $1 \mu \mathrm{M}$ ve $2 \mu \mathrm{M}$ konsantrasyonlardaki niklozamidin hücre canlıı̆ı̆ını azalttığı, 5-FU'nun ise ancak daha yüksek konsantrasyonlarda anlamlı bir proliferasyon inhibisyonu sağladığı bulunmuştur. Niklozamidin apoptoziste artışa neden olduğu ancak 5-FU ile karşılaştırıldığında bu etkinin daha zayıf olduğu belirlenmiştir. Niklozamid uygulaması hücrelerdeki $\beta$-katenin miktarının anlamlı şekilde azalmasına neden olmuş, 5-FU ise $\beta$-katenin seviyelerini etkilememiştir.

Sonuç: Sonuç olarak, niklozamid OVCAR-3 hücrelerinde apoptozisi indüklemekte ve $W n t / \beta-k a t e n i n$ sinyal yolağını inhibe ederek hücre proliferasyonunu baskılamaktadır. Bu bulgular, niklozamidin over kanseri için ümit verici bir tedavi olarak daha fazla incelenmeye değer olduğunu göstermektedir.

Anahtar Sözcükler: OVCAR-3, niklozamid, 5-florourasil, Wnt/ß-katenin proliferasyon, apoptozis

Geliş Tarihi: 21.09 .2018

Kabul Tarihi: 21.12 .2018

This study had been presented as a poster in $15^{\text {th }}$ International Congress of Histochemistry and Cytochemistry (ICHC 2017) in May, 18-21, 2017, Antalya, Turkey.

Address for Correspondence / Yazışma Adresi: Ayşe Çakir Gündoğdu, Department of Histology and Embryology, Faculty of Medicine, Gazi University 06500 Besevler, Ankara, Turkey E-mail: aysecakirgundogdu@gmail.com

CTelif Hakkı 2019 Gazi Üniversitesi Tıp Fakültesi - Makale metnine http://medicaljournal.gazi.edu.tr/ web adresinden ulaşılabilir.

(C) Copyright 2019 by Gazi University Medical Faculty - Available on-line at web site http://medicaljournal.gazi.edu.tr/

doi:http://dx.doi.org/10.12996/gmj.2019.43 
Ovarian cancer is the most lethal gynecological malignancy although it is relatively uncommon among the female cancers (1). This high mortality rate is caused by the diagnosis of ovarian cancer usually at an advanced stage. The standard treatment for advanced ovarian cancer is based on the combination of surgical tumor debulking and chemotherapy with platinum and taxanes. Although the treatment increases survival rates, the overall survival remains poor because most patients eventually develop tumour recurrence (2). Therefore, it is critical to search for novel therapeutic targets and explore new agents for the treatment of ovarian cancer.

Niclosamide (trade name Niclocide) is an oral salicylanilide in the antihelmintic family that is especially effective against cestodes which infects humans (3). It has been approved by FDA for the treatment of various tapeworm infections and has been used in humans for approximately 50 years (4). It is believed that niclosamide exhibits its anthelmintic effects by inhibiting oxidative phosphorylation in the mitochondria of the tapeworm, but its mechanism of the action has not been well defined (5). Niclosamide has been identified as a potential cancer therapeutic agent and has antiproliferative activity in many cancer cells (e.g. head and neck cancer, colon cancer, breast cancer, prostate cancer, non-small cell lung cancer, ovarian cancer and acute myeloid leukemia) (6-12). In the previous studies it has been demonstrated that niclosamide targets multiple signaling pathways including Stat3, NF-kB, ROS, Notch and mTORc1 $(10,12-14)$. Recently, it has been reported that niclosamide can promote downregulation of cytosolic $\beta$-catenin expression to inhibit Wnt/ $\beta$-catenin signaling $(15,16)$.

Wnt/ $\beta$-catenin signaling activation requires the stabilization of cytosolic $\beta$ catenin, which enters the nucleus for the activation of Wnt target genes by binding transcription factors of the T-cell factor and lymphoid enhancing factor (TCF/LEF) family $(17,18)$. If the Wnt ligand does not bind to the receptors on the cell membrane, the pathway is "off" and $\beta$-catenin is degraded by a destruction complex containing Axin, adenomatous polyposis coli (APC), and glycogen synthetase kinase $3 \beta$ (GSK3 $\beta)$. $\beta$-catenin is phosphorylated by the kinases casein kinase 1 (Ck1) and GSK3 $\beta$ followed by ubiquitination and proteasomal degradation by the $26 \mathrm{~S}$ proteasome. The $\mathrm{Wnt}$ ligand binds to the transmembrane receptors causing the Wnt pathway to turn "on," which in turn causes the inhibition of the destruction complex leading to the accumulation of cytosolic $\beta$-catenin. $\beta$-catenin levels increase and it accumulates in the cytoplasm, translocates to the nucleus and regulates expression of specific target genes (17-19). Over 100 target genes regulated by Wnt pathway have been identified and 23 of them are found to be upregulated in ovarian cancer (20).

The $\mathrm{Wnt} / \beta$-catenin signaling pathway plays important roles in the various processes including cell fate specification, differentiation, proliferation, survival, migration, polarity and apoptosis in the great majority of cell types. Abnormalities in the levels and activities of Wnt signaling components may cause defects in embryonic development. Aberrations in the Wnt/ $\beta$-catenin signaling pathway are also observed in variety of types of human cancer (2123). Inhibitors of the Wnt/b-catenin pathway have become a focus of research in trying to find targeted therapeutic agents for the treatment of various cancers.

In the present study we sought to investigate the potential effects of niclosamide in human ovarian cancer cells. We analyzed cytotoxic and apoptotic effects of the drug by MTT and TUNEL assays. In addition we explored the inhibitory action of niclosamide against $\beta$-catenin levels in the cells by using immunocytochemistry. We compared the results to the findings obtained from the anti-cancer agent 5-fluorouracil (5-FU).

\section{METHODS}

\section{Reagents and cell culture}

Niclosamide (2',5-dichloro-4'-nitrosalicylanilide) (N3510) was purchased from Sigma-Aldrich (St. Louis, MO, USA) and was dissolved in DMSO (dimethyl sulfoxide) at a $10 \mathrm{mM}$ concentration. 5-FU (03738) was obtained from Fluka (Italy) and dissolved in DMSO at a $100 \mathrm{mM}$ concentration. Stock drug solutions were stored at $4^{\circ} \mathrm{C}$ before use and diluted in the relevant assay media, and $0.1 \%$ DMSO served as a vehicle control. Human ovarian epithelial adenocarcinoma cell line OVCAR-3 was purchased from American Type Culture Collection (ATCC) (Rockville, MD, USA) and was cultured in RPMI-1640 medium (Lonza, Walkersville, MD) supplemented with $20 \%$ heat inactivated fetal bovine serum (FBS), $1 \%$ penicillin/streptomycin, $0,01 \mathrm{mg} / \mathrm{mL}$ bovine insulin and $1 \mathrm{mM}$ sodium pyruvate (Sigma-Aldrich, St. Louis, MO, USA) at $37^{\circ} \mathrm{C}$ in a humidified incubator with a mixture of $95 \%$ air and $5 \% \mathrm{CO}_{2}$.

Cell proliferation assay
The effects of niclosamide and 5-FU on cell proliferation were determined by 3-(4,5-Dimethylthiazol-2-yl)-2,5-diphenyl-tetrazolium bromide (MTT) assay as previously described, with some modification (24). Briefly, the exponentially growing cells $\left(5 \times 10^{3}\right.$ cells/well) were seeded in 96-well plates. After $48 \mathrm{~h}$ incubation, the cells were treated with various concentrations of niclosamide $(0.2 \mu \mathrm{M}, 0.5 \mu \mathrm{M}, 1 \mu \mathrm{M}, 2 \mu \mathrm{M}, 4 \mu \mathrm{M}, 8 \mu \mathrm{M})$ and 5-FU $(1 \mu \mathrm{M}, 2 \mu \mathrm{M}$, $5 \mu \mathrm{M}, 10 \mu \mathrm{M}, 20 \mu \mathrm{M}, 40 \mu \mathrm{M})$. After incubation for 24,48 and $72 \mathrm{~h}$, the incubation medium was replaced with $25 \mu \mathrm{L} 5 \mathrm{mg} / \mathrm{ml} \mathrm{MTT}$ solution for incubation for $3 \mathrm{~h}$ at $37^{\circ} \mathrm{C}$. The MTT solution was subsequently discarded, and $100 \mu \mathrm{L}$ DMSO was added to dissolve the precipitate completely at room temperature. The optical density (OD) of each well was then measured at 570 nm using a BioTek EL808 microplate spectrophotometer (Winooski, VT, USA). The cell viability was expressed as relative viable cells (\%) to control OVCAR-3 cells and median inhibitory concentration $\left(I_{50}\right)$ values were calculated. Each experiment was performed as quadruplicate and replicated at least 3 times. TUNEL staining

Terminal deoxynucleotidyl transferase-mediated dUTP nick end labeling (TUNEL) assay was used to detect DNA fragmentation and apoptotic cell death in OVCAR-3 cells. The TUNEL assay was performed using the ApopTag ${ }^{\circledR}$ Plus Peroxidase In Situ Apoptosis Detection Kit (Cat no. S7101) (Chemicon, Temecula, CA, USA). OVCAR-3 cells were plated in adherent conditions in round coverslips inserted in 24 -well plates at $3 \times 10^{5}$ cells per well. After $48 \mathrm{~h}$ incubation, the cells were treated with $1 \mu \mathrm{M}$ and $2 \mu \mathrm{M}$ niclosamide or $10 \mu \mathrm{M}$ and $20 \mu \mathrm{M} 5-\mathrm{FU}$ for $48 \mathrm{~h}$. Cells were fixed in $1 \%$ paraformaldehyde and permeabilized with $0.1 \%$ Triton $\mathrm{X}-100$ solution in PBS for 5 min at $4^{\circ} \mathrm{C}$. After endogenous peroxidase was inactivated in $3 \%$ hydrogen peroxide, cells were equilibrated and applied with TdT enzyme in a humidified chamber at $37^{\circ} \mathrm{C}$ for $1 \mathrm{~h}$. Reactions were stopped by incubating cells in stop/wash buffer for $10 \mathrm{~min}$ before proceeding anti-digoxignenin conjugate in a humidified chamber for 30 min. After the cells were applied with peroxidase substrate 3,3'diaminobenzidine (DAB) (00-2020) (Invitrogen, Carlsbad, CA) to detect TUNEL positive cells counterstained in methyl green for $10 \mathrm{~min}$. Stained cells were washed in $100 \% \mathrm{~N}$-butanol and dehydrated in xylene before the coverslips were mounted using mounting medium and examined under computerized photolight microscope (Leica DM4000 B, Germany).

Cells were scanned in the 6 areas ( 1 central and 5 peripheral) of each coverslip. TUNEL index was calculated as percentage of TUNEL-positive nuclei among total number of 100 counted nuclei.

\section{Immunocytochemical staining}

Immunocytochemical staining (ICC) was performed on the cell-bearing coverslips of each experimental group. Rabbit polyclonal anti- $\beta$-catenin (712700) was purchased from Invitrogen (Carlsbad, CA) and used according to the manufacturer's instruction. Briefly, the coverslips were washed with phosphate-buffered solution (PBS, pH 7.4), incubated for 5 minutes in $3 \% \mathrm{H}_{2} \mathrm{O}_{2}$ and epitopes were stabilized by application of serum blocking solution for 5 min. Cells were incubated with diluted primary antibody (1:100) overnight at $4^{\circ} \mathrm{C}$ in a humidity chamber followed by treatments with the biotinylated secondary antibody (859043) (Invitrogen, Carlsbad, CA) for $20 \mathrm{~min}$ and streptavidin peroxidase (859043) (Invitrogen, Carlsbad, CA) enzyme for 20 min. Color reaction was developed using $D A B$ and cells were counterstained with Harris's hematoxylin (008011) (Invitrogen, Carlsbad, CA). Cells were examined under a computerized photolight microscope (Leica DM4000 B, Germany).

Cells with cytoplasmic $\beta$-catenin staining were scanned in the 6 areas (1 central and 5 peripheral) of each coverslip. According to the staining intensity, the staining results were evaluated by two independent researchers and scored as negative (0), faint (1), weak to moderate (2), moderate to strong (4) and strong (5).

Statistical analysis

Data values of MTT assays were given as mean \pm standard deviation (SD). Statistical differences were analyzed by one-way analysis of variance (ANOVA) carried out using SPSS 11.5 for windows (SPSS Inc, Chicago, USA). Scheffe and Tamhane tests were used as a post-hoc method to determine differences among groups and were considered statistically significant when $p<0.001$. SPSS 17.0 for windows (SPSS Inc, Chicago, USA) was used to analyze the data obtained from TUNEL assay and immunocytochemical staining. To determine whether TUNEL-positive cell count in each experimental group is statistically significant, z-test was applied. Proportion of positive cells to total cell number in one group compared with the other groups and differences at $p<0.05$ were considered statistically significant. The nonparametric Kruskal-Wallis test was conducted for comparing $\beta$-catenin staining intensity between groups. Since the statistical significance $(p<0.001)$ was determined, Mann-Whitney $U$ test was used to analyze differential immunostaining in the groups and $p$ values less than 0.05 were considered to be statistically significant. 


\section{RESULTS}

\section{Niclosamide inhibits proliferation of OVCAR-3 cells}

Cytotoxic effect of niclosamide in OVCAR-3 cells was evaluated by MTT assay. OVCAR-3 cells were incubated for 3 days with various concentrations $(1 \sim 40 \mu \mathrm{M})$ of 5-FU to assess the antiproliferative action of the drug. $24 \mathrm{~h}$ after the treatment, there was no significant effect on cell viability. Concentrations $20 \mu \mathrm{M}$ and above of 5-FU significantly inhibited OVCAR-3 cell growth and 20 $\mu \mathrm{M}$ concentration was determined as the $I_{50}$ value of the drug (Figure $1 \mathrm{~A}$ ).
OVCAR-3 cells were exposed to increasing concentrations of niclosamide $\left(0.2^{\sim} 8 \mu \mathrm{M}\right)$ for 24,48 and $72 \mathrm{~h}$. Niclosamide exhibited weak antiproliferative activity against cancer cells after $24 \mathrm{~h}$ incubation. It inhibited cell growth after $48 \mathrm{~h}$ of treatment at $1 \mu \mathrm{M}, 2 \mu \mathrm{M}, 4 \mu \mathrm{M}$ and $8 \mu \mathrm{M}$ concentrations with $50 \%$ inhibition concentration $\left(\mathrm{IC}_{50}\right)$ of $2 \mu \mathrm{M}$. The viability of cells was decreased dramatically after $72 \mathrm{~h}$ exposure of niclosamide (Figure $1 \mathrm{~B}$ )
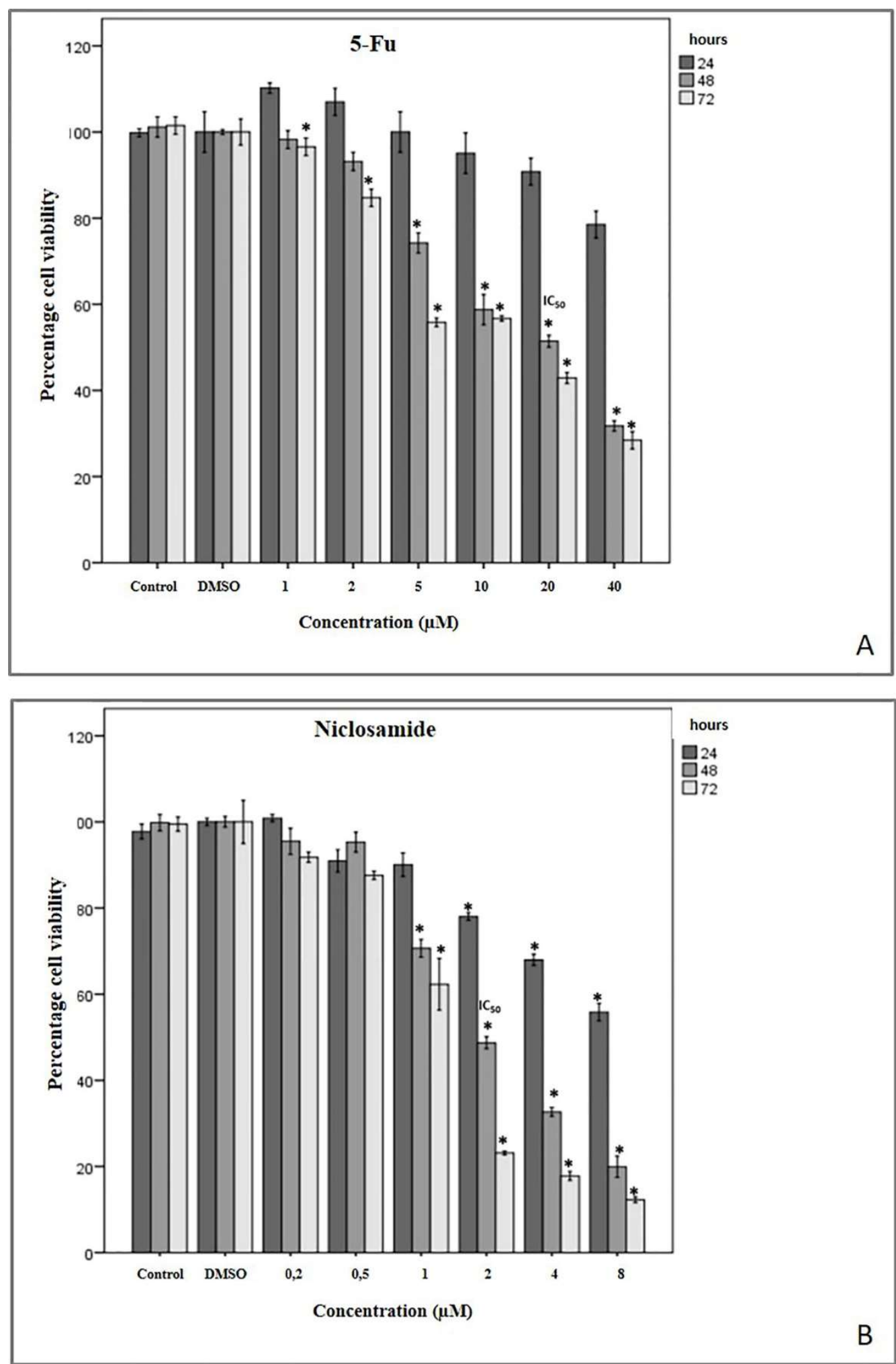

Figure 1. Viability of OVCAR-3 cells treated with drugs for 24,48 and 72 hours, performing MTT test $\left({ }^{*} p \leq 0.001\right)$. DMSO: $0.1 \%$ (v/v). 5-FU treatment (a). Niclosamide treatment (b) 
Data obtained from TUNEL assay showed that niclosamide significantly induced apoptosis in a dose-dependent manner in OVCAR-3 cells compared with the control and the DMSO control.

A


competent to induce apoptosis (Figure 2A). When $10 \mu \mathrm{M}$ and $20 \mu \mathrm{M}$ 5-FU triggered cell death in $63 \%$ and $90 \%$ of OVCAR- 3 cells, apoptotic cell rates were $45 \%$ and $67 \%$ at the $1 \mu \mathrm{M}$ and $2 \mu \mathrm{M}$ niclosamide concentration respectively. Significant differences between groups were analyzed statistically (Figure 2B).

B

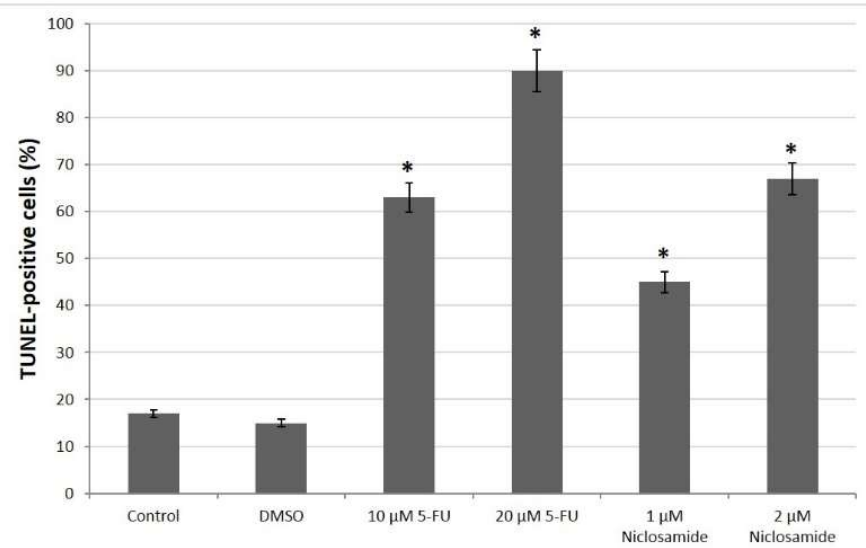

Figure 2. TUNEL staining of OVCAR-3 cells after 5 -FU and niclosamide exposure for $48 \mathrm{~h}$. TUNEL-positive cells $(\triangleright)$, TUNEL-negative cells $(\Delta)$, nucleus $(\rightarrow)$, nucleolus $(\triangle)$, cytoplasm $(\leftrightarrow)$, weakly stained cells $\left({ }^{*}\right)$, ondulation on cell membrane $(\downarrow)$, nucleus with damaged chromatin structure $(+)$, nuclear fragments as apoptotic bodies ( $(\Theta)$ and lobulated nucleus ( $(\mathbb{)})$. Scale bars: $50 \mu \mathrm{m}$ for $A, B, C, D, E, F ; 20 \mu m$ for $A^{\prime}, B^{\prime}, C^{\prime}, D^{\prime}, E^{\prime}, F^{\prime}$ (A). TUNEL-positive cell percentages compared between groups $\left({ }^{*} p<0.001\right)(B)$

\section{Wnt/B-catenin pathway inhibition in OVCAR-3 cells by niclosamide}

To elucidate the effects of niclosamide on $\beta$-catenin levels immunocytochemical staining was performed and location and relative abundance of the protein were evaluated. $\beta$-catenin was distributed in cell membrane and cytoplasm of OVCAR-3 cells under normal culture conditions. Strong membranous and moderate cytoplasmic staining was observed in the control and DMSO control cells. After $1 \mu \mathrm{M}$ niclosamide treatment for $48 \mathrm{~h}$, staining intensity became weaker. At the $2 \mu \mathrm{M}$ concentration of niclosamide, $\beta$-catenin staining was significantly decreased. Most of the cells showed negative immunoreactivity whereas weak cytoplasmic staining was detected in a small number of cells (Figure $3 \mathrm{~A}$ ). Intensity comparisons between groups showed that reducing effect of niclosamide on $\beta$-catenin levels in the cells was statistically significant (Figure $3 \mathrm{~B}$ ). Staining protocol was also performed for the $10 \mu \mathrm{M}$ and $20 \mu \mathrm{M}$ concentrations of the 5-FU and reactivity intensity was found quite similar to control and DMSO control at both concentrations (Figure 3A). There were no statistically significant differences among control, DMSO control and 5-FU groups (Figure 3B). 
A
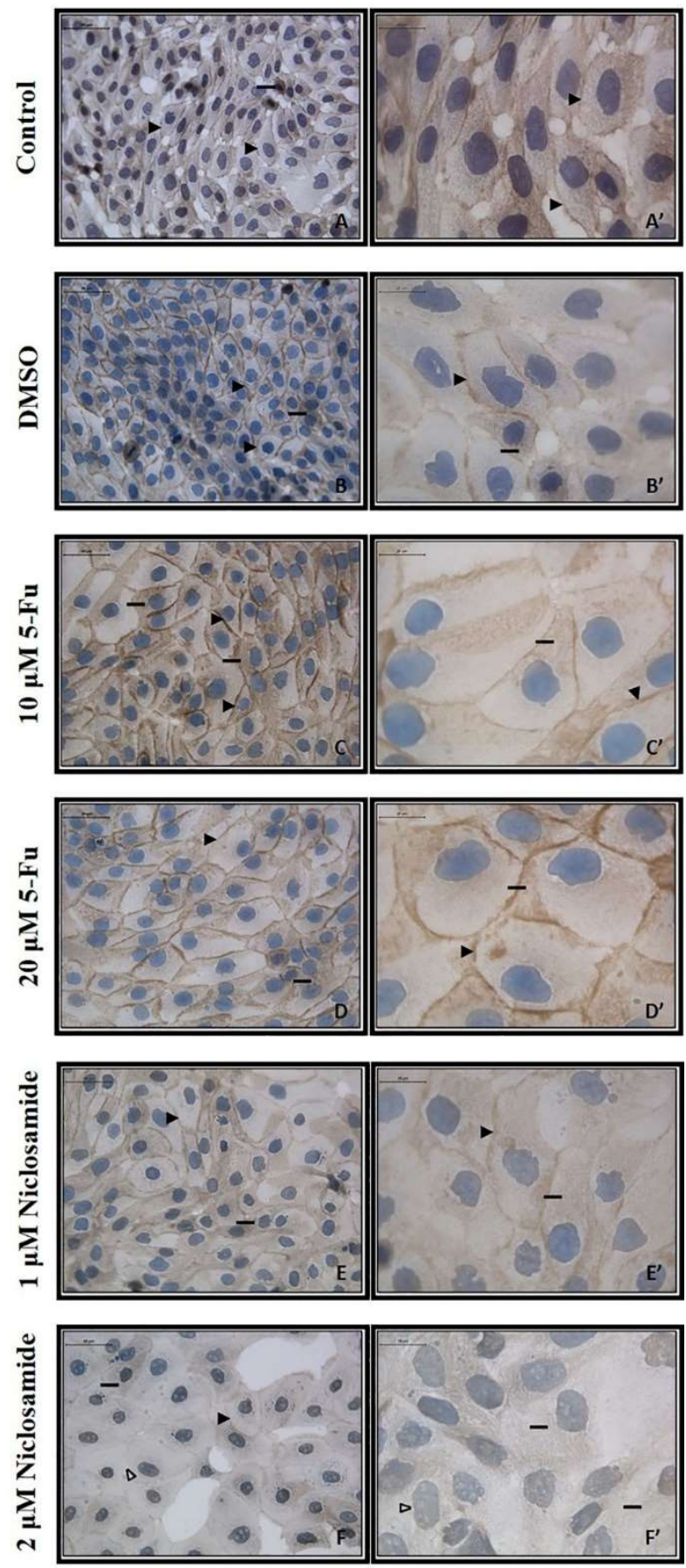



Figure 3. Immunocytochemistry analysis of OVCAR-3 cells stained with $\beta$ catenin antibody after 5 -FU and niclosamide exposure for $48 \mathrm{~h}$. Membranous staining $(-)$, cytoplasmic staining $(-)$, and negative staining $(\Delta)$. Scale bars: $50 \mu \mathrm{m}$ for $\mathrm{A}, \mathrm{B}, \mathrm{C}, \mathrm{D}, \mathrm{E}, \mathrm{F} ; 20 \mu \mathrm{m}$ for $\mathrm{A}^{\prime}, \mathrm{B}^{\prime}, \mathrm{C}^{\prime}, \mathrm{D}^{\prime}, \mathrm{E}^{\prime}, \mathrm{F}^{\prime}(\mathrm{A})$. $\beta$-catenin staining intensity of OVCAR-3 cells compared between groups $\left({ }^{*} p<0.001\right)$ (B)

\section{DISCUSSION}

Development of novel anticancer drugs that show less toxicity and are able to be administrated orally is important to improve the ovarian cancer treatment. Repurposing existing drugs that have been used for other indications to find new uses is an attractive strategy for the drug development process. Niclosamide is a salicylic acid derivative anti-helminthic drug that is effective against human tapeworms. It has low toxicity in mammals (oral LD 50 in rats, $>5,000 \mathrm{mg} / \mathrm{kg}$ ) and is safe $(25,26)$. Niclosamide has been recently investigated for use in cancer therapy because of its convenient properties.

It has been demonstrated that niclosamide is able to inhibit cell proliferation and induce apoptosis at very low concentrations in many human cancer cells. $\mathrm{IC}_{50}$ value was found to be less than $1 \mu \mathrm{M}$ and niclosamide induced apoptosis at 1.2 and $2.4 \mu \mathrm{M}$ concentrations in prostate and breast cancer cell lines (14). Significant anti-proliferative actions were detected at niclosamide concentrations $0.5-1.0 \mu \mathrm{M}$ and the apoptotic induction was established in multiple myeloma cells (27). In the present study, we demonstrated the potential therapeutic activity of niclosamide against human ovarian cancer cells. Niclosamide inhibited cell proliferation in a dose- and time-dependent fashion. We showed that niclosamide displayed a significant anti-proliferative effect at a concentration as low as $2 \mu \mathrm{M}$ after $48 \mathrm{~h}$ incubation of OVCAR-3 cells. This action was greater than 5-FU, the anti-cancer drug which is already used for treatment of several cancers, whose $\mathrm{IC}_{50}$ value has been found to be $20 \mu \mathrm{M}$ against OVCAR-3 cells in dose-response experiments. We also determined that niclosamide was able to induce ovarian cancer cell apoptosis significantly at $2 \mu \mathrm{M}$ concentration compared to the control $(p<0.05)$. However, $20 \mu \mathrm{M}$ of 5 -FU was more potent than niclosamide in apoptosis induction after $48 \mathrm{~h}$ incubation and this finding was validated with statistical comparison $(p<0.001)$. Our data revealed that niclosamide is a potential therapeutic agent for ovarian cancer.

The $\mathrm{Wnt} / \beta$-catenin signaling pathway is involved in tissue development and homeostasis. The target genes of the pathway regulate cell proliferation and apoptosis, and evidences indicated that aberrant up-regulation of this pathway promotes tumorigenesis of a variety of cancers (3-5). Dysregulation of Wnt/ $\beta$-catenin signaling on the cell membrane, in the cytoplasm, and in the nucleus leads to aberrant activation of pathway and is involved in carcinogenesis of ovarian cancer (8). Thus, targeting the Wnt/ $\beta$-catenin pathway is a promising new approach for the ovarian cancer therapy. Several studies demonstrated that niclosamide could inhibit $\mathrm{Wnt} / \beta$-catenin signaling by down-regulating cytosolic $\beta$-catenin expression $(22,23)$.

Yo et al. used a drug screening method with more than 1200 clinically approved drugs and demonstrated that niclosamide selectively inhibits the growth of stem-like ovarian cancer-initiating cells by modulating metabolic signaling pathways including Wnt pathway (18). A significant reduction of $W n t / \beta$-catenin signaling was observed in tumor cells isolated from patients' ascites with primary ovarian cancer treated with niclosamide and carboplatin combination (28). 
It has been reported that more soluble niclosamide analogs are able to produce cytotoxicity and inhibit Wnt signaling in ovarian cancer patient samples (29). King et al. reported that niclosamide inhibits WNT7A levels and TCF/LEF activity stimulated by a constitutively active $\beta$-catenin in human ovarian cancer cells (30). In this study, we investigated the status of $\mathrm{Wnt} / \beta$ catenin signaling in OVCAR-3 cells and effects of niclosamide on the pathway. This was the first study which uses immunocytochemistry to investigate the $W n t / \beta$-catenin signaling pathway mediated cell proliferation inhibitory effect of the drug on OVCAR-3 cells. We showed that cytosolic $\beta$-catenin levels were increased in the cancer cells and after $2 \mu \mathrm{M}$ niclosamide treatment for $48 \mathrm{~h}$, cytoplasmic distribution of $\beta$-catenin was significantly reduced compared to the control $(p<0.05)$. There was no statistically significant alteration of $\beta$ catenin labeling following 5 -FU treatment of cells $(p>0.05)$. These data suggest that niclosamide is a potent Wnt/ $\beta$-catenin signaling inhibitor by inhibiting cytosolic $\beta$-catenin accumulation in ovarian cancer cells.

In conclusion, our data indicate that niclosamide inhibits ovarian cancer cell growth and induces apoptosis in vitro at low concentrations. Its antiproliferative activity might be caused by inhibiting $W n t / \beta$-catenin signaling pathway in ovarian cancer cells. Niclosamide is a candidate monotherapy or in combination with current chemotherapeutics for the treatment ovarian cancer and worthy of further investigations.

\section{Conflict of interest}

No conflict of interest was declared by the authors.

\section{REFERENCES}

1. Lowe KA, Chia VM, Taylor A, O'Malley C, Kelsh M, Mohamed M, et al. An international assessment of ovarian cancer incidence and mortality. Gynecol Oncol 2013; 130:107-114.

2. Vargas-Hernández VM, Moreno-Eutimio MA, Acosta-Altamirano G, Vargas-Aguilar VM. Management of recurrent epithelial ovarian cancer. Gland Surg 2014; 3:198-202.

3. Garin J, Despeignes J, Billerau M: Present treatment of taeniasis with niclosamide. Lyon Med 1964; 212:1581-8.

4. Pearson RD, Hewlett EL. Niclosamide therapy for tapeworm infections. Ann Intern Med 1985; 102:550-1.

5. Weinbach EC, Garbus J. Mechanism of action of reagents that uncouple oxidative phosphorylation. Nature 1969; 221:1016-8.

6. Li R, You S, Hu Z, Chen ZG, Sica GL, Khuri FR, et al. Inhibition of STAT3 by niclosamide synergizes with erlotinib against head and neck cancer. PloS one 2013; 8: e74670.

7. Shi L, Zheng H, Hu W, Zhou B, Dai X, Zhang Y, Liu Z, Wu X, Zhao C, Liang G. Niclosamide inhibition of STAT3 synergizes with erlotinib in human colon cancer. Onco Targets Ther 2017; 10:1767-776.

8. Gangrade A, Pathak V, Augelli-Szafran CE, Wei HX, Oliver P, Suto M, et al. Preferential Inhibition of Wnt/ $\beta$-Catenin Signaling by Novel Benzimidazole Compounds in Triple-Negative Breast Cancer. Int J Mol Sci 2018; 19. pii: E1524.

9. Schweizer MT, Haugk K, McKiernan JS, Gulati R, Cheng HH, Maes JL, et al. A phase I study of niclosamide in combination with enzalutamide in men with castration-resistant prostate cancer. PLoS One 2018; 13:e0198389.

10. Li R, Hu Z, Sun SY, Chen ZG, Owonikoko TK, Sica GL, et al. Niclosamide overcomes acquired resistance to erlotinib through suppression of STAT3 in non-small cell lung cancer. Mol Cancer Ther 2013; 12):2200-12.

11. Yo YT, Lin YW, Wang YC, Balch C, Huang RL, Chan MWY, et al. Growth inhibition of ovarian tumor-initiating cells by niclosamide. Mol Cancer Ther 2012; 11:1703-12.
12. Jin Y, Lu Z, Ding K, Li J, Du X, Chen C, et al. Antineoplastic mechanisms of niclosamide in acute myelogenous leukemia stem cells: inactivation of the NF-kB pathway and generation of reactive oxygen species. Cancer Res 2010; 70:2516-27.

13. Suliman $\mathrm{MA}$, Zhang $\mathrm{Z}, \mathrm{Na} \quad \mathrm{H}$, Ribeiro $\mathrm{AL}$, Zhang $\mathrm{Y}$, Niang $\mathrm{B}$, et al. Niclosamide inhibits colon cancer progression through downregulation of the Notch pathway and upregulation of the tumor suppressor miR-200 family. Int J Mol Med 2016; 38:776-84.

14. Chen L, Wang L, Shen $H$, Lin H, Li D. Anthelminthic drug niclosamide sensitizes the responsiveness of cervical cancer cells to paclitaxel via oxidative stress-mediated mTOR inhibition. Biochem Biophys Res Commun 2017; 484:416-21.

15. Chen $M$, Wang J, Lu J, Bond $M C$, Ren XR, Lyerly HK, et al. The antihelminthic niclosamide inhibits Wnt/Frizzled1 signaling. Biochemistry 2009; 48:10267-74.

16. Osada T, Chen M, Yang XY, Spasojevic I, Vandeusen JB, Hsu D, et al. Antihelminth compound niclosamide downregulates Wnt signaling and elicits antitumor responses in tumors with activating APC mutations. Cancer Res 2011; 71:4172-82.

17. Kikuchi A, Yamamoto $\mathrm{H}$, Kishida S. Multiplicity of the interactions of Wnt proteins and their receptors. Cell Signal 2007; 19:659-71.

18. MacDonald BT, Tamai $K$, He X. Wnt/ $\beta$-catenin signaling: components, mechanisms, and diseases. Dev Cell 2009; 17:9-26.

19. Arend RC, Londoño-Joshi Al, Straughn JM, Buchsbaum DJ. The Wnt/ $\beta$ catenin pathway in ovarian cancer: a review. Gynecol Oncol 2013; 131:772-9.

20. Barbolina MV, Burkhalter RJ, Stack MS. Diverse mechanisms for activation of Wnt signalling in the ovarian tumour microenvironment. Biochem 2011; 437:1-12.

21. Boyer A, Goff AK, Boerboom D. WNT signaling in ovarian follicle biology and tumorigenesis. TEM 2010; 21:25-32.

22. Dakeng $S$, Duangmano $S$, Jiratchariyakul $W$, Bögler $O$, Patmasiriwat $P$. Inhibition of Wnt signaling by cucurbitacin B in breast cancer cells: Reduction of Wnt-associated proteins and reduced translocation of galectin-3-mediated $\beta$-catenin to the nucleus. J Cell Biochem 2012; 113:49-60.

23. Anastas JN, Moon RT. WNT signalling pathways as therapeutic targets in cancer. Nat Rev Cancer 2013; 13:11-26.

24. Mosmann, T. Rapid colorimetric assay for cellular growth and survival: application to proliferation and cytotoxicity assays methods. J Immunol Methods 1983; 16:55-63.

25. Organization WH. WHO Specifications and Evaluations for Public Health Pesticides (niclosamide). Geneva: World Health Organization; 2002; 1-24.

26. Chang YW, Yeh TK, Lin KT, Chen WC, Yao HT, Lan SJ, et al. Pharmacokinetics of anti-SARS-CoV agent niclosamide and Its analogs in rats. J Food Drug Anal 2006; 14:329-33.

27. Khanim FL, Merrick BAME, Giles HV, Jankute M, Jackson JB, Giles L, et al. Redeployment-based drug screening identifies the anti-helminthic niclosamide as anti-myeloma therapy that also reduces free light chain production. Blood Cancer J 2011; 1:e39.

28. Arend RC, Londoño-Joshi Al, Samant RS, Li Y, Conner M, Hidalgo B, et al. Inhibition of Wnt/ $\beta$-catenin pathway by niclosamide: A therapeutic target for ovarian cancer. Gynecol Oncol 2014); 134:112-20.

29. Walters Haygood CL, Arend RC, Gangrade A, Chettiar S, Regan N, Hassmann $\mathrm{CJ}$, et al. Niclosamide Analogs for Treatment of Ovarian Cancer. Int J Gynecol Cancer 2015; 25:1377-85.

30. King $M L$, Lindberg $M E$, Stodden $G R$, Okuda $H$, Ebers $S D$, Johnson $A$, et al. WNT7A/ $\beta$-catenin signaling induces FGF1 and influences sensitivity to niclosamide in ovarian cancer. Oncogene 2015; 34:3452-62. 